\title{
Invading the Mediterranean Sea: biodiversity patterns shaped by human activities
}

\section{Stelios Katsanevakis ${ }^{1}$, Marta Coll ${ }^{2}$, Chiara Piroddi ${ }^{1}$, Jeroen Steenbeek ${ }^{3}$, Frida Ben Rais Lasram ${ }^{4}$, Argyro Zenetos $^{5}$ and Ana Cristina Cardoso ${ }^{1}$}

${ }^{1}$ Water Resources Unit, Institute for Environment and Sustainability, Joint Research Centre, Ispra, Italy

2 Institut de Recherche pour le Développement, UMR EME 212, Centre de Recherche Halieutique Méditerranéenne et Tropicale, Sète, France

${ }^{3}$ Ecopath International Initiative Research Association, Barcelona, Spain

${ }^{4}$ Unité de Recherche Ecosystèmes et Ressources Aquatiques UR03AGRO1, Institut National Agronomique de Tunisie, Tunis, Tunisia

${ }^{5}$ Institute of Marine Biological Resources and Inland Waters, Hellenic Centre for Marine Research, Agios Kosmas, Greece

\section{Edited by:}

Christos Dimitrios Arvanitidis,

Hellenic Centre for Marine

Research, Greece

Reviewed by:

Melih Ertan Çinar, Ege University,

Turkey

Salud Deudero, Instituto Español de

Oceanografia, Spain

Christos Dimitrios Arvanitidis,

Hellenic Centre for Marine

Research, Greece

Theodoros Tzomos, Aristotle

University of Thessaloniki, Greece

*Correspondence:

Stelios Katsanevakis, Water

Resources Unit, Institute for

Environment and Sustainability,

Joint Research Centre, Via E. Fermi

2749, Building 46 (TP 460), Ispra

1-21027, Italy

e-mail: stelios@katsanevakis.com
Human activities, such as shipping, aquaculture, and the opening of the Suez Canal, have led to the introduction of nearly 1000 alien species into the Mediterranean Sea. We investigated how human activities, by providing pathways for the introduction of alien species, may shape the biodiversity patterns in the Mediterranean Sea. Richness of Red Sea species introduced through the Suez Canal (Lessepsian species) is very high along the eastern Mediterranean coastline, reaching a maximum of 129 species per $100 \mathrm{~km}^{2}$, and declines toward the north and west. The distribution of species introduced by shipping is strikingly different, with several hotspot areas occurring throughout the Mediterranean basin. Two main hotspots for aquaculture-introduced species are observed (the Thau and Venice lagoons). Certain taxonomic groups were mostly introduced through specific pathways-fish through the Suez Canal, macrophytes by aquaculture, and invertebrates through the Suez Canal and by shipping. Hence, the local taxonomic identity of the alien species was greatly dependent on the dominant maritime activities/interventions and the related pathways of introduction. The composition of alien species differs among Mediterranean ecoregions; such differences are greater for Lessepsian and aquaculture-introduced species. The spatial pattern of native species biodiversity differs from that of alien species: the overall richness of native species declines from the north-western to the south-eastern regions, while the opposite trend is observed for alien species. The biodiversity of the Mediterranean Sea is changing, and further research is needed to better understand how the new biodiversity patterns shaped by human activities will affect the Mediterranean food webs, ecosystem functioning, and the provision of ecosystem services.

Keywords: alien species, biological invasions, Lessepsian migrants, aquaculture, shipping, pathways, biodiversity patterns

\section{INTRODUCTION}

The Mediterranean Sea is a hotspot of marine biodiversity with $>17,000$ reported marine species, of which approximately one fifth are considered to be endemic (Coll et al., 2010). Such increased endemism and high species richness makes the Mediterranean Sea one of the world's biodiversity hotspots (Lejeusne et al., 2010). However, Mediterranean marine ecoregions are amongst the most impacted ecoregions globally (Halpern et al., 2008; Costello et al., 2010), due to increasing levels of human threats that affect all levels of biodiversity (Mouillot et al., 2011; Coll et al., 2012; Micheli et al., 2013), severe impacts from climate change (Lejeusne et al., 2010), and biological invasions (Zenetos et al., 2012; Katsanevakis et al., 2013).

Introduction of marine alien species in the Mediterranean Sea has been fostered by the opening of the Suez Canal, fouling and ballast transportation along shipping routes, aquaculture, and aquarium trade (Zenetos et al., 2012; Katsanevakis et al.,
2013). Nearly 1000 marine alien species have been introduced in the Mediterranean up to now, of which more than half are considered to be established and spreading (Zenetos et al., 2010, 2012). Marine alien species may become invasive and displace native species, cause the loss of native genotypes, modify habitats, change community structure, affect food-web properties and ecosystem processes, impede the provision of ecosystem services, impact human health, and cause substantial economic losses (Grosholz, 2002; Wallentinus and Nyberg, 2007; Molnar et al., 2008; Vilà et al., 2010; Katsanevakis et al., in press). On the other hand many alien species have positive impacts on ecosystem services and biodiversity, e.g., by acting as ecosystem engineers and creating novel habitats, controlling other invasive species, providing food, and supporting ecosystem functioning in stressed or degraded ecosystems (Schlaepfer et al., 2011; Simberloff et al., 2013; Katsanevakis et al., in press). Understanding the role of biological invasions in modifying biodiversity patterns and the 
functionality of ecosystems is a major challenge for marine ecosystems ecology (Borja, 2014).

In the Mediterranean Sea, despite the variability in monitoring and reporting effort among countries and the gaps in our knowledge of alien species distribution, there is an enormous amount of information scattered in various databases, institutional repositories, and the literature (including single- or multi-species reviews). By harmonizing and integrating information that has often been collected based on different protocols and is distributed in various sources (Gatto et al., 2013), the needed knowledge basis to assess the distribution and status of marine alien species can be built. Recently, the European Alien Species Information Network (EASIN; Katsanevakis et al., 2012) increased the accessibility to alien species spatial information by creating a network of interoperable web services through which data in distributed sources is accessed. Integrated distribution maps of single species or species aggregations can be easily produced with EASIN's freely available mapping tools.

Here, we utilize information on alien species distribution from EASIN to investigate the distribution patterns of marine alien species in the Mediterranean Sea, in relation to the main pathways of introduction. We investigate how specific human activities (opening of the Suez Canal, shipping, aquaculture) may shape the patterns of alien species distribution and consequently the overall biodiversity patterns in the Mediterranean Sea. We also compare the distributions of alien species with those of native ones to investigate differences in their patterns, and thus induced changes in pre-existing distribution patterns of native biodiversity.

\section{MATERIALS AND METHODS}

The EASIN alien species inventory was used (available online in: http://easin.jrc.ec.europa.eu/use-easin/species-search/ combined-criteria-search) as of January 2014 (version 3.2 of the EASIN catalog). The link between alien species and pathways was based on Zenetos et al. (2012) and Katsanevakis et al. (2013); the pathway classification proposed by the latter authors was used herein. For each species one of the following uncertainty categories on the pathway(s) of introduction was adopted:

(1) There is direct evidence of a pathway/vector: The species was clearly associated to a specific pathway/vector at the time of introduction to a particular locality. This is the case e.g., in all intentional introductions (i.e., aquaculture/commodity) and in many cases of Lessepsian immigrants, when there was direct evidence of a gradual expansion along the Suez Canal and then in the localities around the exit of the Canal in the Mediterranean).

(2) A most likely pathway/vector can be inferred: The species appears for the first time in a locality where a single pathway/vector(s) is known to operate and there is no other rational explanation for its presence except by this pathway/vector(s). This applies e.g., to many species introduced by shipping or as aquaculture contaminants. In many cases inference is based on known examples of introductions elsewhere for the same or similar species, the biology and ecology of the species, the habitats it occupies in both the native and introduced range, and its pattern of dispersal (if known), e.g., for a fouling species frequently recorded in/near ports, shipping has been assumed to be the most probable vector.

(3) One or more possible pathways/vectors can be inferred: The species cannot be convincingly ascribed to a single pathway/vector. Inference is based on the activities in the locality where the species was found and may include evidence on similarly behaving species reported elsewhere.

(4) Unknown: Where there is doubt as to any specific pathway explaining the arrival of the species.

Of the 986 species reported from the Mediterranean, 799 have been assigned to a single pathway, 114 have been assigned to two or more possible pathways, and the remaining 73 species have been classified as "unknown" (Zenetos et al., 2012). In the present analysis of spatial distribution by pathway only species linked to a single pathway were included (i.e., species of uncertainty categories 1 and 2). Species of uncertainty category 3 were excluded from any pathway-specific analysis to avoid the distortion of pathway-related spatial patterns by erroneously including species that might actually have been introduced through another pathway. In the absence of a permanent monitoring network and of a biased effort favoring specific locations (e.g., ports, marinas, and aquaculture facilities), some uncertainty remains (especially for category 2 species). All alien species were included in all other analyses (non-pathway-specific).

The "Species Search/Mapping By Multiple Criteria" tool of EASIN was used to select and map species introduced in the Mediterranean by the three major pathways of introduction, i.e., (1) through the Suez Canal; (2) by shipping; and (3) by aquaculture (Figure 1). The spatial data used herein through EASIN originate from the following sources: (1) the CIESM Atlas of Exotic Species (http://www.ciesm.org/online/atlas/index.htm); (2) the Global Biodiversity Information Facility (GBIF; http://www.gbif. org/); (3) the Global Invasive Species Information Network (GISIN; http://www.gisin.org); (4) the Regional Euro-Asian Biological Invasions Centre (REABIC; http://www.reabic.net/); (5) the Hellenic Network on Aquatic Invasive species (ELNAIS: https://services.ath.hcmr.gr/); and (6) EASIN-Lit (http://easin. jrc.ec.europa.eu/About/EASIN-Lit). EASIN-Lit is an EASIN product providing georeferenced records as retrieved from published literature (Trombetti et al., 2013). For the present work, we used the current (as of January 2014) version of EASIN-Lit, including 227 publications (L00001-L00227; full references in http://easin.jrc.ec.europa.eu/About/EASIN-Lit).

To investigate spatial patterns in the composition of alien communities, we randomly "sampled" five sites in each of the seven Mediterranean ecoregions (sensu Spalding et al., 2007, i.e., Levantine, Aegean, Ionian, Adriatic, Tunisian plateau and Gulf of Sidra, western Mediterranean, Alboran Sea); only in the western Mediterranean ecoregion, seven sites were "sampled" due to its relatively larger size. In derogation of the random sampling approach, we included the Venice and the Thau lagoons, as these sites have been well-studied and highlighted in the literature as hotspots of alien species (Occhipinti Ambrogi, 2000; Boudouresque et al., 2011). For each site (considered to be a $10 \times 10 \mathrm{~km}$ quadrat), the list of recorded alien species was retrieved from EASIN (presence/absence data). 


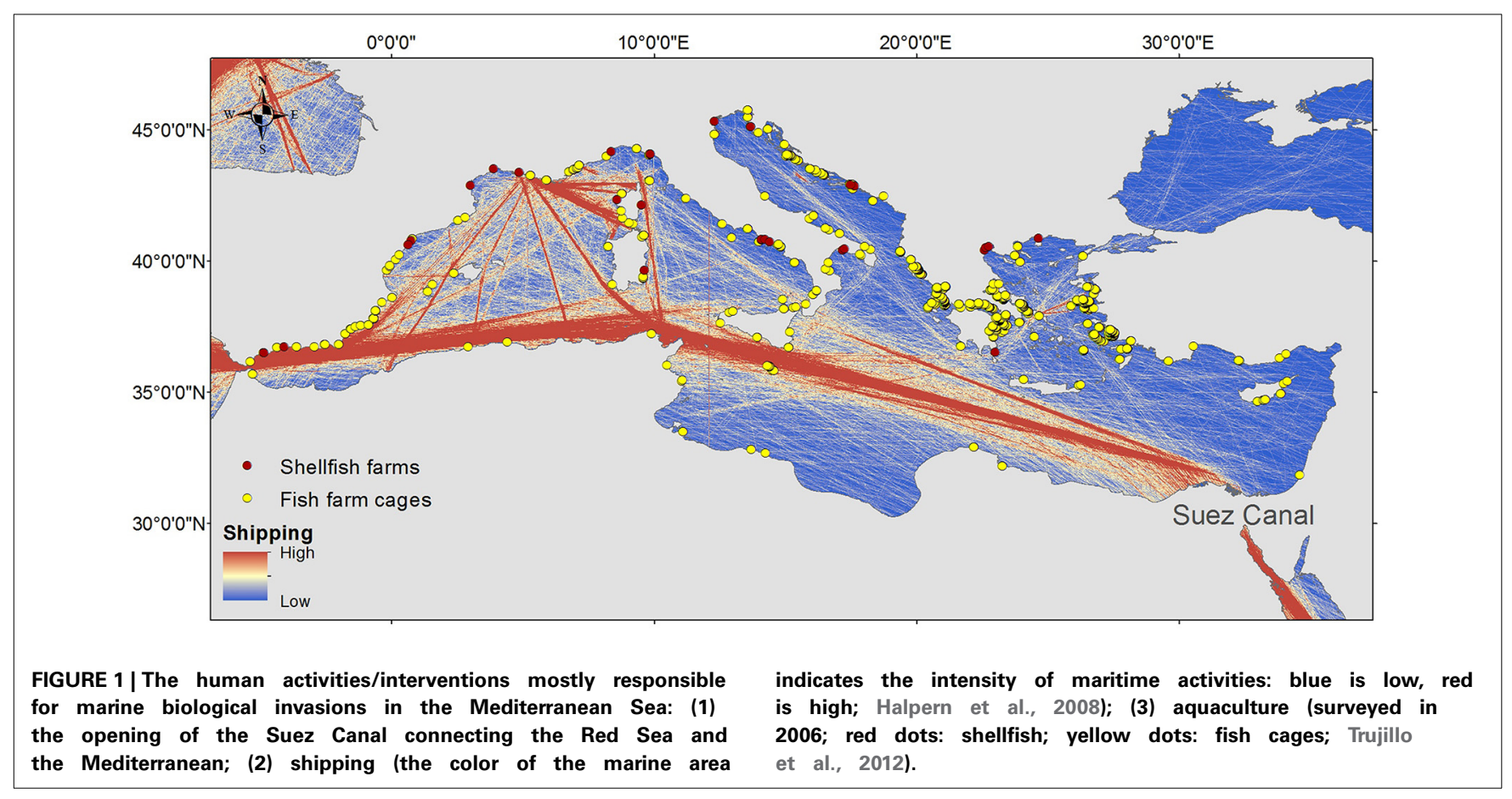

Similarity patterns were explored through non-metric multidimensional scaling (nMDS; Kruskal, 1964), based on a similarity matrix constructed using the Jaccard coefficient (Jaccard, 1901). Permutational multivariate analysis of variance (Permanova; Anderson, 2001) was used to test for differences among ecoregions, using type III sum of squares and 999 random permutations of the appropriate units. The software Primer 6 was used for multivariate analysis (Clarke and Warwick, 2001) and Permanova + v.1.0.3 for the PERMANOVA analysis.

We also included available data regarding the spatial distribution of native fish and invertebrate species described in the Mediterranean Sea (Coll et al., 2010, 2012) to compare the spatial patterns of species richness between native and alien species. For fish species we used data available from the "Fishes of the Northern Atlantic and Mediterranean" (FNAM atlas; Whitehead et al., 1986) updated and integrated by Ben Rais Lasram and Mouillot (2009) and Coll et al. (2012). Data on invertebrates were compiled from the Food and Agriculture Organization of the United Nations (FAO: www.fao.org/fishery/species/distribution) and the Sea Around Us (www.seaaroundus.org) databases (Coll et al., 2012). To estimate the distribution of native species richness, we grouped all the species as the sum of the species co-occurring by overlapping distribution maps at fine-scale resolution $(10 \times 10 \mathrm{~km})$.

We assessed the spatial congruence of native and alien species by calculating the correlation coefficient between the native and alien raster layers, i.e., the ratio of the covariance between the two layers divided by the product of their standard deviations. Only the cells adjacent to the coastline were included in this analysis, as alien species are generally concentrated in coastal and shelf waters (otherwise the overabundance of zero values in the offshore cells would mask any significant correlation). For this estimation, we used the Band Collection Statistics tool in ArcGis 10. The ratio of alien to native species richness was also estimated for each $10 \times$ $10 \mathrm{~km}$ cell, as an indicator of the environmental impact of alien species (EC, 2010).

\section{RESULTS}

A total of 420 species of uncertainty levels 1 and 2 have been introduced in the Mediterranean Sea through the Suez Canal. An aggregated map of these Lessepsian species (Figure 2) shows a characteristic pattern of high species richness in the south-eastern Levantine Sea, which declines anticlockwise along the coastline of the Levantine Sea and further westwards and northwards along the northern Mediterranean coast, and also westwards along the north-African coastline. In the Israeli coastline, species richness reaches a maximum of 129 species per $10 \times 10 \mathrm{~km}$ cell (in the Haifa coastal area), while it is markedly lower in the Ionian Sea, the Adriatic Sea, and the western Mediterranean basin.

Shipping, through ballast waters and hull-fouling, was the most probable pathway for the introduction of 308 species (uncertainty levels 1 and 2). The distribution of these species (Figure 3) is strikingly different to the one of Lessepsian species. Hotspot areas include the north-western Mediterranean coastline from Martigues and Marseille (France) to Genova (Italy), eastern Sicily (Italy), the Saronikos, Thermaikos and Evvoikos Gulfs (Greece), and the coastlines of the eastern Levantine (SE Turkey, Syria, Israel, and Lebanon).

Through aquaculture, either as commodities or as contaminants, 64 species have been introduced in the Mediterranean Sea (uncertainty levels 1 and 2). Two main hotspot areas were identified, the Thau lagoon (Gulf of Lion, France), and the Venice lagoon (northern Adriatic, Italy) (Figure 4). Most of species introduced through aquaculture are macrophytes (41 species) 


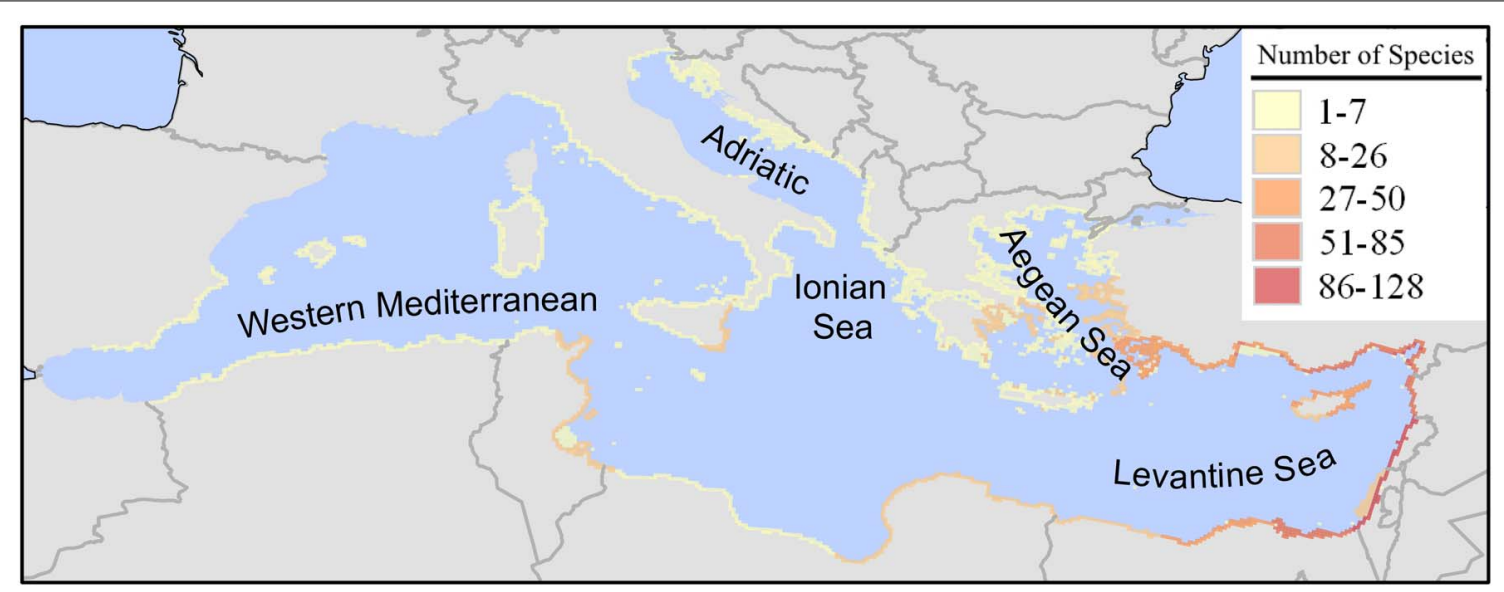

FIGURE 2 | Richness (number of species in a $10 \times 10 \mathbf{~ k m}$ grid) of marine alien species introduced in the Mediterranean Sea through the Suez Canal (Lessepsian immigrants). Map was produced by EASIN's mapping widget.

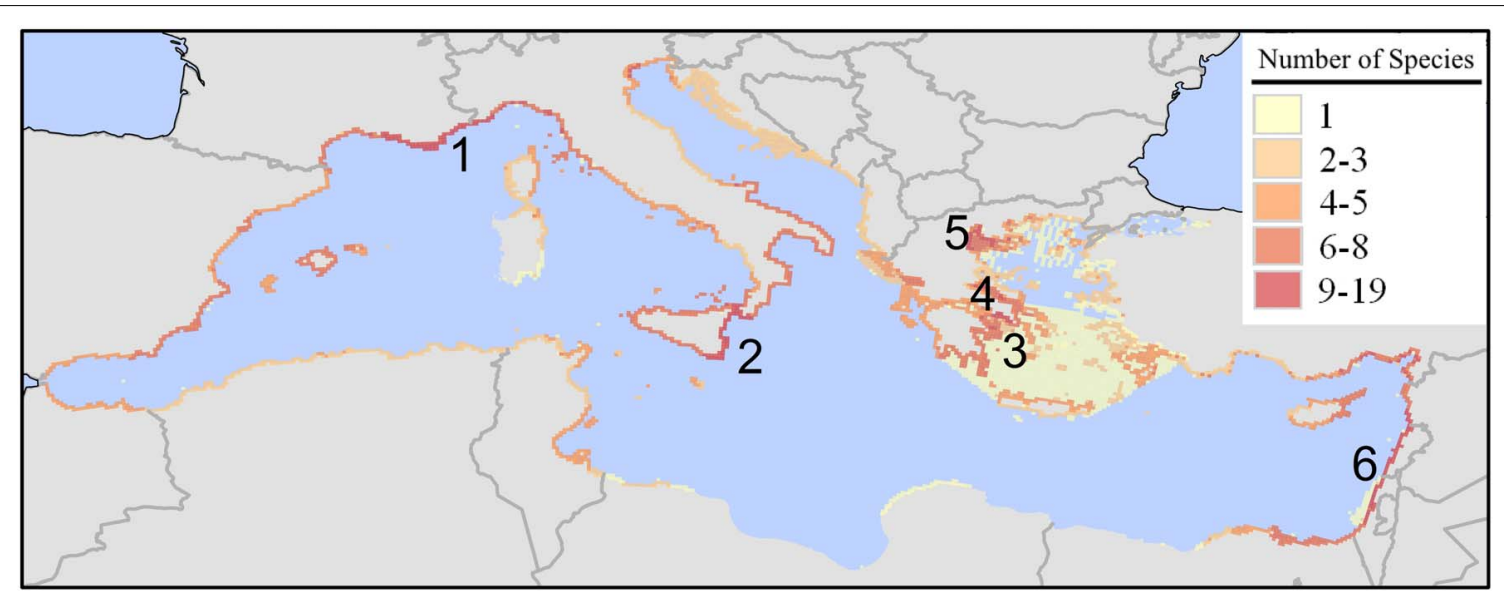

FIGURE 3 | Richness (number of species in a $10 \times 10 \mathrm{~km}$ grid) of marine alien species introduced in the Mediterranean Sea by shipping. Map was produced by EASIN's mapping widget. High-richness areas: (1) north-western
Mediterranean coastline from Martigues and Marseille (France) to Genova (Italy); (2) eastern Sicily; (3) Saronikos Gulf; (4) Evvoikos Gulf; (5) Thermaikos Gulf; (6) the coastlines of SE Turkey, Syria, Israel, and Lebanon. and invertebrates (14 species) that arrived as contaminants of shellfish. Richness of species introduced by aquaculture is quite low in the Near East and northern African coastlines, with the exception of northern Tunisia (Figure 4).

There is a difference in the magnitude of species richness among the species introduced through the Suez Canal, shipping, and aquaculture (Figures 2-4). Much higher maximum values of species richness per $10 \times 10 \mathrm{~km}$ cell are reached for Lessepsian species than for species introduced through aquaculture and shipping, although the total number of species introduced via shipping is not much lower than those introduced through the Suez Canal. This indicates the higher contribution of Lessepsian species in the overall spatial pattern of species richness of all alien species.

Besides differences in the spatial patterns of species richness by pathway, varying patterns among the main taxonomic groups are also observed (Figure 5). Alien fish richness is the highest in the
Levantine and the southeastern part of the Aegean Sea and the lowest in the western and northern regions of the Mediterranean. For alien invertebrates, the spatial pattern of species richness is similar but there are some additional areas of increased richness such as the French coastline around the Thau lagoon, northern Adriatic, and eastern Sicily. Richness of alien macrophytes has a quite different spatial pattern, with increased richness in the western Mediterranean. These patterns are linked to the dominant pathways of introduction for each group, i.e., the Suez Canal for fish, aquaculture for macrophytes, and the Suez Canal but also shipping for invertebrates (Figure 5).

Alien species composition differs among ecoregions (Figure 6). With the exception of the Venice lagoon (site 18) and the Thau lagoon (site 24) that appear more similar to each other than to other sites of the same ecoregions (western Mediterranean and Adriatic, respectively), sites from the same ecoregion appear close together in the nMDS plot. Excluding 

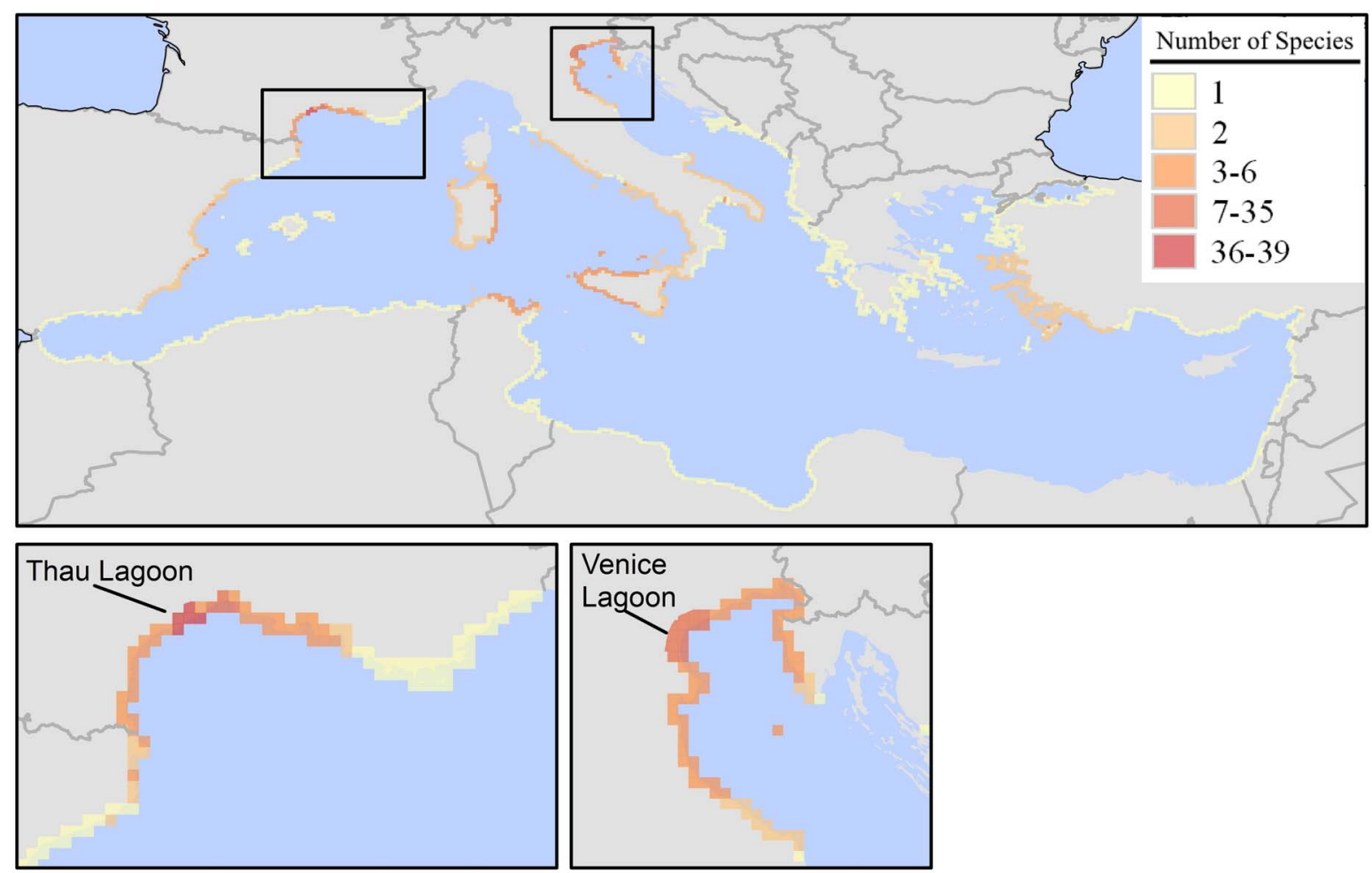

FIGURE 4 | Richness (number of species in a $10 \times 10 \mathrm{~km}$ grid) of marine alien species introduced in the Mediterranean Sea by aquaculture (either as commodities or contaminants). Map was produced by EASIN's mapping widget.

these two outliers (sites 18, 24), PERMANOVA showed significant differences among ecoregions $(p<0.001)$. Pairwise tests gave $p$-values $<0.05$ for all pairs of ecoregions except for Ionian-Adriatic $(p=0.06)$ and Alboran-western Mediterranean $(p=0.06)$. Similarity appears well-correlated to geographical distance, with sites of the Levantine being more similar to sites of the Tunisian plateau and Gulf of Sidra and the Aegean Sea than to sites of the Adriatic, western Mediterranean, and Alboran Sea. Sites of the latter ecoregions are grouped closely in the nMDS plot, while the Ionian Sea is in the middle of all other ecoregions, in conformity to its geographical location.

The biodiversity spatial pattern of native species (fish and invertebrates) differs to that of alien species (Figure 7). The highest richness is observed in the Western Mediterranean Sea with a maximum of 391 species in a $10 \times 10 \mathrm{~km}$ cell. Native species richness decreases from the north-western to the south-eastern regions of the basin, where a minimum value of 84 species is mapped. Native species richness is also higher in coastal and shelf areas, and decreases with depth. The correlation coefficient between alien and native species richness (in coastal areas) was -0.25 (significant, $p<0.001$ ), thus the two distributions are negatively correlated.

The highest estimated values of the ratio of alien to native species richness are observed in the eastern Mediterranean (especially in the Levantine and the south-eastern Aegean Sea), with a maximum value of 0.69 (Figure 8). In the central and eastern Mediterranean, the alien to native species ratio is much lower.

\section{DISCUSSION}

The evidence herein provided demonstrates how human activities and interventions (shipping, aquaculture, opening of the Suez Canal) modify large-scale biodiversity patterns in the Mediterranean Sea by assisting biological invasions. In the Mediterranean Sea, a northwestern-to-southeastern gradient of native species richness is observed, although this could be, at least partly, due to gaps in our knowledge of the biota along the southern and eastern rims (Figure 7; Coll et al., 2010, 2012; Bianchi et al., 2012). Native biodiversity is generally higher in coastal and shelf waters in most groups of both vertebrates and invertebrates, with some local exceptions. Similarly, alien species are concentrated in coastal and shelf waters. Very few alien species have been reported in offshore areas, which may be explained by the thriving of shallow-water thermophilic demersal aliens, or because important vectors of alien species (ships and aquaculture) operate in shallow waters, but also due to the reduced sampling effort off-shore (Danovaro et al., 2010). However, the opposite (in relation to native biodiversity) basin-wide trend of alien species richness is observed, decreasing from southeast to northwest. Biodiversity patterns are substantially modified, and locally the induced change in species composition, abundance and richness can be even more marked. For example, in the Thau Lagoon (Figure 4) at least 58 introduced macrophytes have been identified, representing $32 \%$ of the species diversity and $48-99 \%$ of the macrophyte biomass on hard substrates (Boudouresque et al., 2011). 

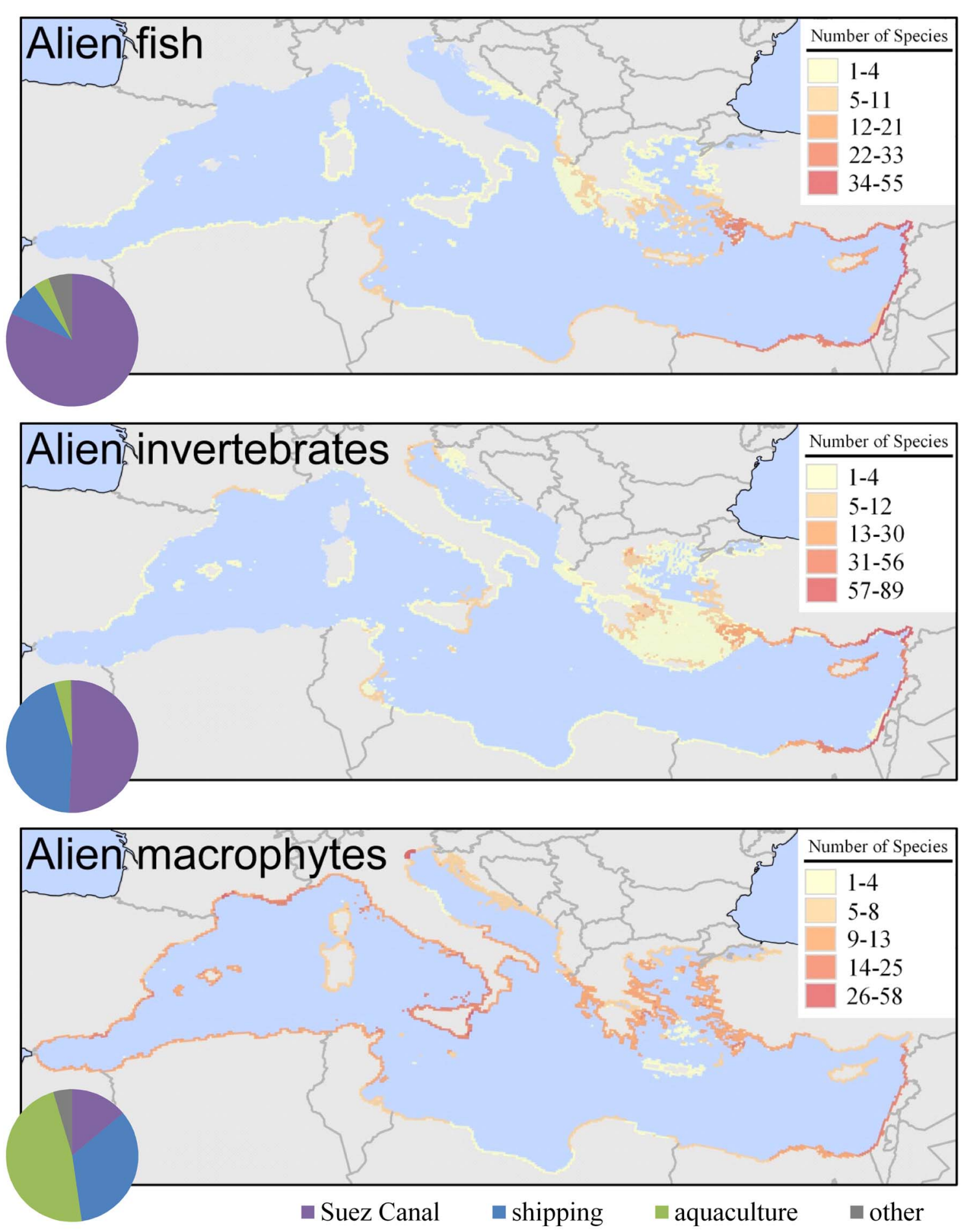

FIGURE 5 | Richness (number of species in a $10 \times 10 \mathrm{~km}$ grid) of alien fish, invertebrates, and macrophytes in the

Mediterranean Sea.The pie charts depict the relative importance of the three main pathways for each taxonomic group (only uncertainty levels 1 and 2 were included). Maps were produced by EASIN's mapping widget.
In several hotspot areas, alien species now constitute a substantial part of the communities and have in many cases caused a shift to novel habitats, with an entirely modified ecosystem functioning (Katsanevakis et al., in press). Species richness per $10 \times 10 \mathrm{~km}$ cell is generally markedly higher for Lessepsian species than for species introduced by shipping or aquaculture. In the eastern Mediterranean (Levantine Sea), this high richness of alien species is highly reflected also in terms of total biomass and community 

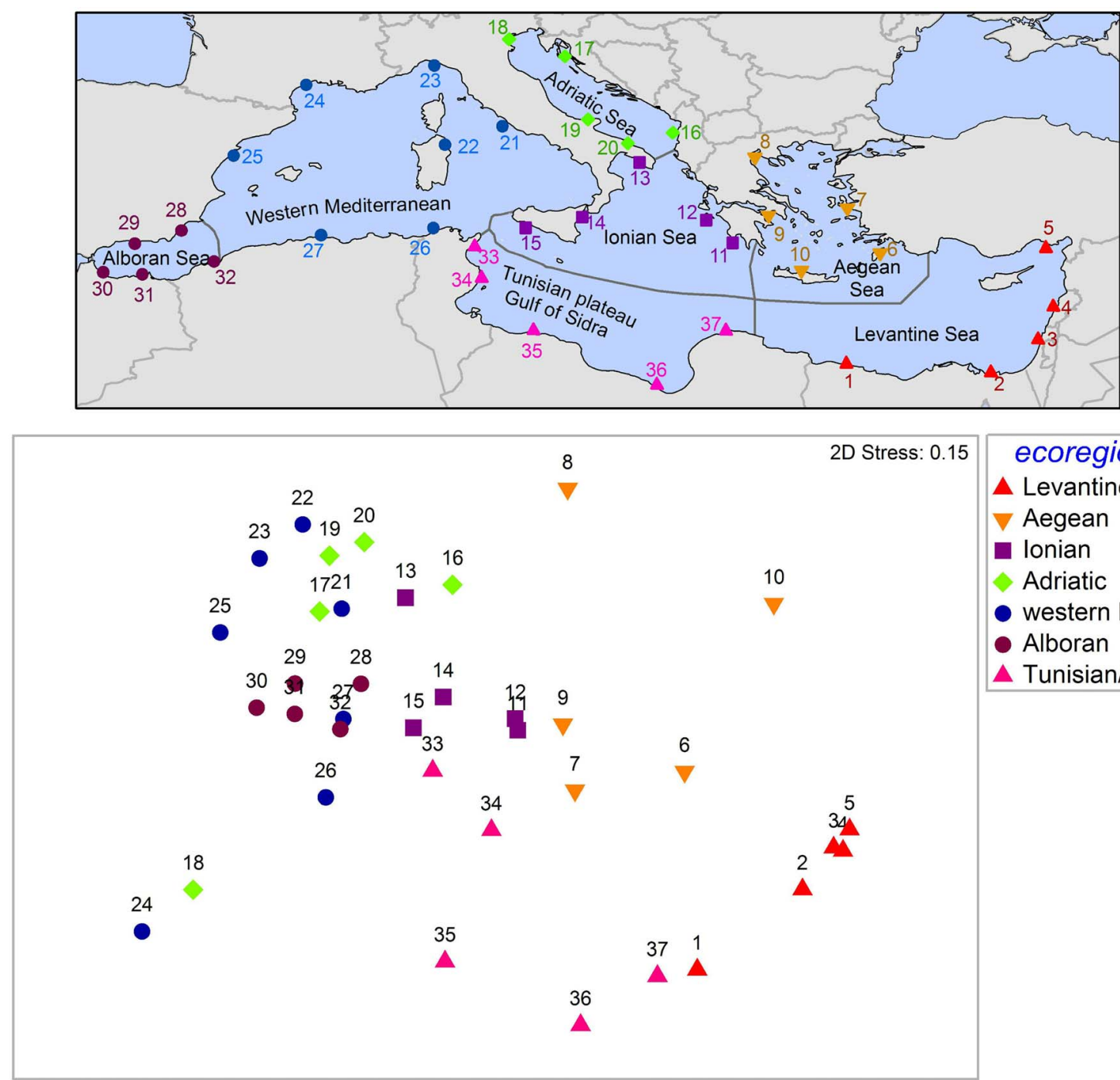

FIGURE 6 | Top panel: The 37 "sampling" sites in the seven Mediterranean ecoregions (sensu Spalding et al., 2007). Presence/ absence data for these sites were retrieved from EASIN. Site 18:
Venice lagoon; site 24: Thau lagoon. Bottom panel: nMDS graph of the 37 sites, based on Jaccard similarity. The underlying dataset is available as a Supplementary File. structure. The proportion of alien fish in trawl catches along the Levantine continental shelf has been increasing, reaching $54 \%$ in abundance and 55\% in biomass ( 84 and 66\%, respectively for the 15-30 m depth stratum) (Edelist et al., 2013).

Most of the alien species that are established in the Mediterranean Sea were introduced in the last decades. Less than 200 alien species were introduced in the Mediterranean before 1950 , while $>800$ species have been introduced after that date (Zenetos et al., 2012). Hence, the observed large-scale change of biodiversity patterns in the Mediterranean is a phenomenon that has been evolving mainly during the last century. This unprecedented change has been greatly driven by the opening of the Suez Canal in 1869 and its continuous enlargement, but also by the increasing seaborne trade, responsible for many shippingmediated introductions, and the intentional introduction of alien commodity species (and, unintentionally, of contaminant species) for aquaculture (Katsanevakis et al., 2013; Nunes et al., 2014).

Herein, we focused on species richness as an indicator of biodiversity, as is common in the ecological literature (May, 1995; Bianchi and Morri, 2000). Alien species richness and the ratio between alien and native species (Figure 8) were used as indicators of biodiversity change and impact. Another indicator that has been previously used is the change in the intensity of spatial congruence between alien and endemic fauna (Ben Rais Lasram and Mouillot, 2009). However, in many cases these indicators are not the best to indicate biodiversity change or impact. Some individual keystone and high-impact alien species can have a much more severe impact than dozens of other non-invasive aliens. For example, the two herbivore rabbitfish Siganus luridus and $S$. rivulatus have radically altered the community structure and the native food web of the rocky infralittoral zone in the 


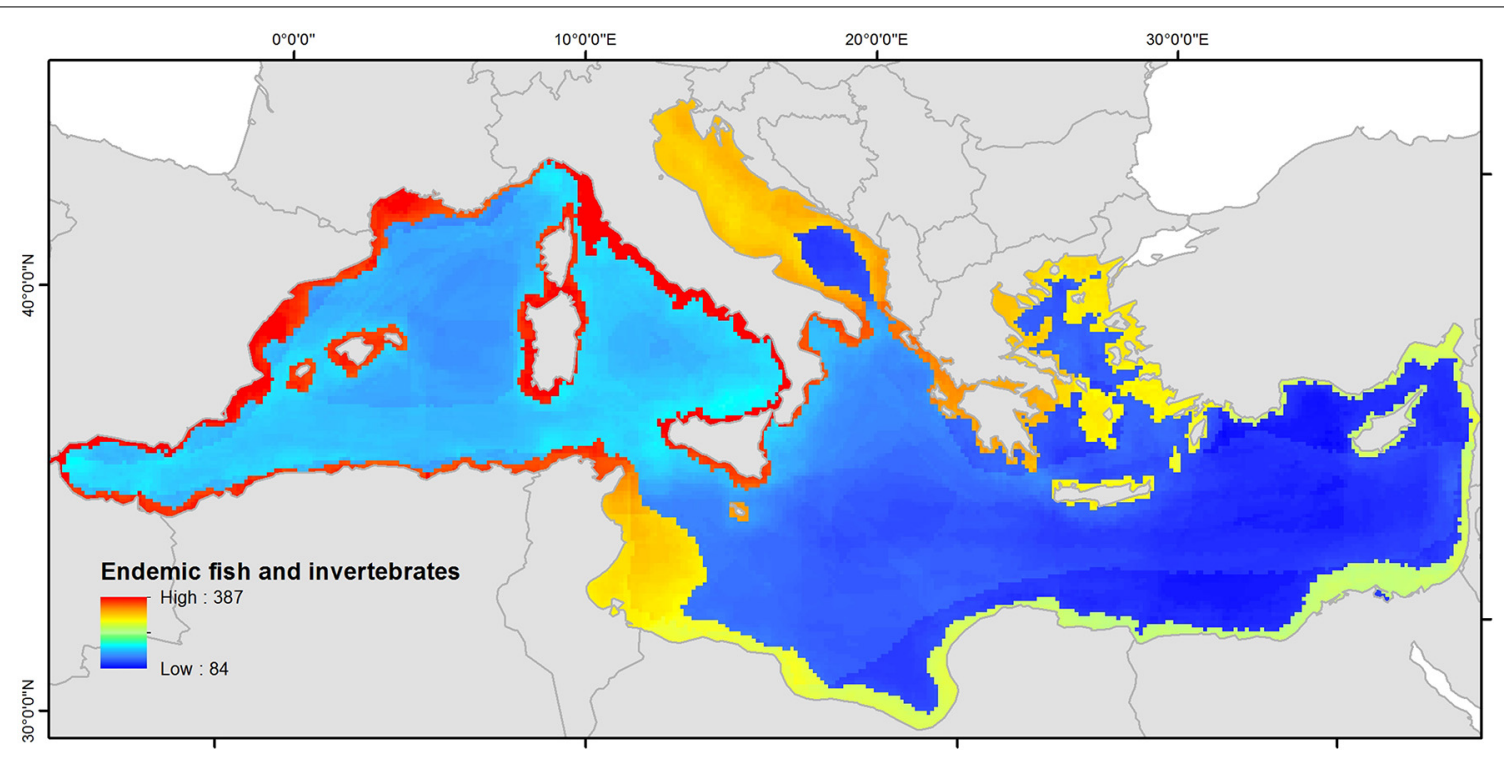

FIGURE 7 | Richness (number of species in a $\mathbf{1 0} \times \mathbf{1 0} \mathbf{~ k m}$ grid) of native fish and invertebrates in the Mediterranean Sea. The data are plotted using a linear scale from minimum to maximum values.

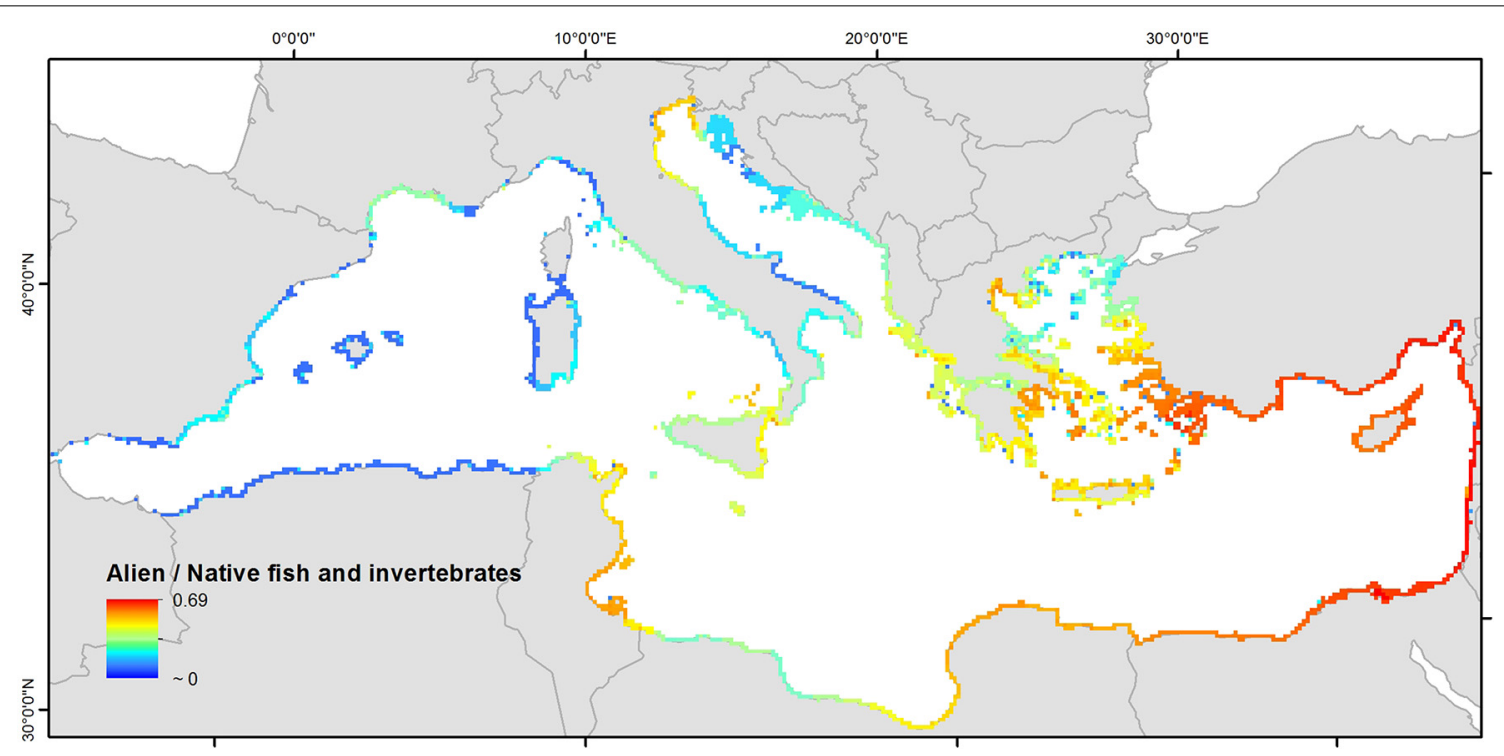

FIGURE 8 | Alien-to-native ratio of fish and invertebrates richness in the coastal areas of the Mediterranean Sea. Note:

Distributional data were available for a limited number of native invertebrates and thus the absolute values of this indicator appear elevated. However, this is not expected to affect the spatial patterns depicted in this figure. eastern Mediterranean, through overgrazing. They are able to create and maintain barrens (rocky areas almost devoid of erect algae) and contribute to the transformation of the ecosystem from one dominated by lush and diverse brown algal forests to a degraded one dominated by bare rock and patches of crustose coralline algae (Sala et al., 2011; Giakoumi, 2014). The largescale and severe impact of these two species in the shallow rocky shores of the eastern Mediterranean is probably greater than that of the other alien fish in the Mediterranean altogether, which is not depicted by a species richness indicator. Similarly, a few very invasive macroalgae can dominate algal assemblages creating homogenized microhabitats, greatly impacting native communities. This is the case of the invasive green alga Caulerpa cylindracea, which can easily overgrow and eliminate other macroalgal or invertebrate species and may form compact multilayered mats up to $15 \mathrm{~cm}$ thick that trap sediment and may create an anoxic layer underneath (Klein and Verlaque, 2008; Katsanevakis et al., in press). Several biotopes, such as Mediterranean communities 
of sublittoral algae and coralligenous communities, are affected by C. cylindracea, which smothers indigenous populations, outcompetes native communities, and diminishes the structural complexity and species richness. This species alone can have much greater impact than dozens of other non-invasive alien macrophytes, which again is not evident in an alien species richness indicator.

The ecosystems of many regions of the Mediterranean Sea have been substantially modified (Boudouresque et al., 2011; Sala et al., 2011; Edelist et al., 2013). Especially Lessepsian migration is considered as the most significant biogeographic change currently underway worldwide (Bianchi et al., 2012). Although so far there are no recorded basin-wide extinctions of native marine species in the Mediterranean, there are many examples of local extirpations and range shifts concurrent with alien invasions (Galil, 2007). Hence, $\boldsymbol{\gamma}$-diversity has increased in the Mediterranean by $>5 \%$ due to the overall increase of species richness, while $\alpha$-diversity has locally decreased in some cases (see the Siganus spp. example above) and increased in others because of the habitat-specific increase of species richness. However, there is no evidence so far of extensive basin-wide taxonomic homogenization of the Mediterranean biota due to biological invasions. There are marked differences in the introduced biota among ecoregions (Figure 6), which is more intense for Lessepsian and aquacultureintroduced species. Hence, at a Mediterranean scale, communities are continuously changing but there is no sign of a reduced degree of heterogeneity across ecoregions. This may not be the case at smaller scales (e.g., among habitats within an ecoregion), possibly leading to an important decrease of $\beta$-diversity within ecoregions. The effect of biological invasions on $\beta$-diversity is greatly dependent on scale (Olden, 2006) and needs further investigation.

The future of the Mediterranean Sea biota is difficult to predict. During the past two decades, Mediterranean waters have been warming at a rather high rate, especially in the eastern region, and this trend is predicted to continue in the longterm influencing biogeochemical cycles and ecosystem functioning (Durrieu de Madron et al., 2011; Macias et al., 2013). The sea surface temperature contours are shifted northwards (Coll et al., 2010) and the boundaries of Mediterranean ecoregions are expected to change substantially. Warming of the Mediterranean Sea favors the establishment and spread of thermophilic species, such as most of the Lessepsian migrants (Bianchi, 2007; Bianchi et al., 2013). The high incidence of alien species of tropical affinity and origin is driving the eastern Mediterranean biota toward a phase of "tropicalization" (Bianchi and Morri, 2003). At least in the Levant Basin, environmental conditions are favorable for communities of Indo-Pacific hermatypic corals, and the arrival and establishment of the first reef builders and a great diversity of associated fish and invertebrates is probably only a matter of time (Por, 2009).

A better understanding of how the human-shaped new biodiversity patterns will affect the Mediterranean food webs, ecosystem functioning, and the provision of ecosystem services for the benefit of humans is challenging (Borja, 2014) but urgently needed. A possible way to assess this is through the employment of ecosystem models, which in the last decades have been increasingly used worldwide to evaluate ecosystem structure and functions and the impacts of human activities on marine systems (e.g., Christensen and Walters, 2004; Shin et al., 2004; Fulton, 2010). Despite the ability of some ecosystem models to provide useful indicators to address biological invasions, gaps still remain in relation to the understanding of role/impact of alien species in the food web (Piroddi et al., under review). Thus, future studies should be set up and carried out to assess and better understand alien species in an ecosystem context.

Alien species often benefit some components of native biodiversity and can enhance or provide new ecosystem services (Katsanevakis et al., in press). In marine regions subject to rapid change, such as the Mediterranean Sea, introduced species may even secure ecosystem processes and functioning (Walther et al., 2009). It is unknown if the future Mediterranean ecosystems will be more resilient, and may continue to provide the same ecosystem services, but it is likely they will be very different than the past ecosystems before the major wave of biological invasions of the last century.

\section{AUTHOR CONTRIBUTIONS}

Stelios Katsanevakis and Ana Cristina Cardoso conceived the study. Data on native species distributions were provided by Frida Ben Rais Lasram and Marta Coll. Analysis of pathways of introduction was conducted by Argyro Zenetos and Stelios Katsanevakis. The mapping of human activities was provided by Chiara Piroddi. Stelios Katsanevakis created the alien species maps and conducted the MDS analysis of Figure 6. Mapping of native species distribution, estimation and mapping of aliento-native ratios, and related spatial analyses were conducted by Marta Coll, Jeroen Steenbeek, and Frida Ben Rais Lasram. Stelios Katsanevakis prepared a first draft of the manuscript and all coauthors contributed to the final version.

\section{SUPPLEMENTARY MATERIAL}

The Supplementary Material for this article can be found online at: http://www.frontiersin.org/journal/10.3389/fmars.2014. 00032/abstract

\section{REFERENCES}

Anderson, M. J. (2001). A new method for non-parametric multivariate analysis of variance. Aust. Ecol. 26, 32-46. doi: 10.1111/j.1442-9993.2001.01070.pp.x

Ben Rais Lasram, F., and Mouillot, D. (2009). Increasing southern invasion enhances congruence between endemic and exotic Mediterranean fish fauna. Biol. Invasions 11, 697-711. doi: 10.1007/s10530-008-9284-4

Bianchi, C. N. (2007). Biodiversity issues for the forthcoming tropical Mediterranean Sea. Hydrobiologia 580, 7-21. doi: 10.1007/s10750-006-0469-5

Bianchi, C. N., Boudouresque, C. F., Francour, P., Morri, C., Parravicini, V., Templado, J., et al. (2013). The changing biogeography of the Mediterranean Sea: from the old frontiers to the new gradients. Boll. Mus. Ist. Biol. Univ. Genova 75, 81-84.

Bianchi, C. N., and Morri, C. (2000). Marine biodiversity of the Mediterranean Sea: situation, problems and prospects for future research. Mar. Pollut. Bull. 40, 367-376. doi: 10.1016/S0025-326X(00)00027-8

Bianchi, C. N., and Morri, C. (2003). Global sea warming and 'tropicalization' of the Mediterranean Sea: biogeographic and ecological aspects. Biogeographia 24, 319-327.

Bianchi, C. N., Morri, C., Chiantore, M., Montefalcone, M., Parravicini, V., and Rovere, A. (2012). "Mediterranean Sea biodiversity between the legacy from the 
past and a future of change," in Life in the Mediterranean Sea: a Look at Habitat Changes, ed N. Stambler (New York, NY: Nova Science Publishers), 1-60.

Borja, A. (2014). Grand challenges in marine ecosystems ecology. Front. Mar. Sci. 1:1. doi: 10.3389/fmars.2014.00001

Boudouresque, C. F., Klein, J., Ruitton, S., and Verlaque, M. (2011). "Biological invasion: the Thau Lagoon, a Japanese biological island in the Mediterranean Sea," in Global Change: Mankind-Marine Environment Interactions, Proceedings of the 13th French-Japanese Oceanography Symposium, eds H. J. Ceccaldi, I. Dekeyser, M. Girault, and G. Stora (Dordrecht: Springer), 151-156.

Christensen, V., and Walters, C. (2004). Ecopath with ecosim: methods, capabilities and limitations. Ecol. Model. 72, 109-139. doi: 10.1016/j.ecolmodel.2003.09.003

Clarke, K. R., and Warwick, R. M. (2001). Change in Marine Communities: an Approach to Statistical Analysis and Interpretation, 2nd Edn. Plymouth: PRIMER-E.

Coll, M., Piroddi, C., Albouy, C., Ben Rais Lasram, F., Cheung, W. W. L., Christensen, V., et al. (2012). The Mediterranean under siege: spatial overlap between marine biodiversity, cumulative threats and marine reserves. Glob. Ecol. Biogeogr. 21, 465-481. doi: 10.1111/j.1466-8238.2011. 00697.x

Coll, M., Piroddi, C., Steenbeek, J., Kaschner, K., Ben Rais Lasram, F., Aguzzi, J., et al. (2010). The biodiversity of the Mediterranean Sea: estimates, patterns and threats. PLOS ONE 5:e11842. doi: 10.1371/journal.pone. 0011842

Costello, M. J., Coll, M., Danovaro, R., Halpin, P., Ojaveer, H., and Miloslavich, P. (2010). A census of marine biodiversity knowledge, resources and future challenges PLOS ONE 5:e12110. doi: 10.1371/journal.pone. 0012110

Danovaro, R., Company, B. J., Corinaldesi, C., D’Onghia, G., Galil, B. S., Gambi, C., et al. (2010). Deep-Sea biodiversity in the Mediterranean Sea: the known the unknown and the unknowable. PLoS ONE 5:e11832. doi: 10.1371/journal.pone.0011832

de Madron, X. D., Guieu, C., Sempéré, R., Conan, P., Cossa, D., D’Ortenzio, F., et al. (2011). Marine ecosystems' responses to climatic and anthropogenic forcings in the Mediterranean. Prog. Oceanogr. 91, 97-166. doi: 10.1016/j.pocean.2011.02.003

EC. (2010). European Commission Decision 2010/477/EU on criteria and methodological standards on good environmental status of marine waters. J. Eur. Union L 53, 232/14. doi: 10.3000/17252555.L_2010.232.eng

Edelist, D., Rilov, G., Golani, D., Carlton, J. T., and Spanier, E. (2013). Restructuring the Sea: profound shifts in the world's most invaded marine ecosystem. Divers. Distrib. 19, 69-77. doi: 10.1111/ddi.12002

Fulton, E. A. (2010). Approaches to end-to-end ecosystem models. J. Marine Syst. 81, 171-183. doi: 10.1016/j.jmarsys.2009.12.012

Galil, B. S. (2007). Loss or gain? Invasive aliens and biodiversity in the Mediterranean Sea. Mar. Pollut. Bull. 55, 314-322. doi: 10.1016/j.marpolbul.2006.11.008

Gatto, F., Katsanevakis, S., Vandekerkhove, J., Zenetos, A., and Cardoso, A. C. (2013). Evaluation of online information sources on alien species in Europe the need of harmonization and integration. Environ. Manag. 51, 1137-1146. doi: $10.1007 /$ s00267-013-0042-8

Giakoumi, S. (2014). Distribution patterns of the invasive herbivore Siganus luridus (Rüppell, 1829) and its relation to native benthic communities in the central Aegean Sea, Northeastern Mediterranean. Mar. Ecol. 35, 96-105. doi: $10.1111 /$ maec. 12059

Grosholz, E. (2002). Ecological and evolutionary consequences of coastal invasions. Trends Ecol. Evol. 17, 22-27. doi: 10.1016/S0169-5347(01)02358-8

Halpern, B. S., Walbridge, S., Selkoe, K. A., Kappel, C. V., Micheli, F., D’Agrosa, C. et al. (2008). A global map of human impact on marine ecosystems. Science 319, 948-952. doi: 10.1126/science.1149345

Jaccard, P. (1901). Étude comparative de la distribution florale dans une portion des Alpes et des Jura. Bull. Soc. Vaudoise Sci. Nat. 37: 547-579.

Katsanevakis, S., Bogucarskis, K., Gatto, F., Vandekerkhove, J., Deriu, I., and Cardoso, A. C. (2012). Building the European Alien Species Information Network (EASIN): a novel approach for the exploration of distributed alien species data. Bioinvasions Rec. 1, 235-245. doi: 10.3391/bir.2012. 1.4 .01

Katsanevakis, S., Wallentinus, I., Zenetos, A., Leppäkoski, E., Çinar, M. E., Oztürk, B., et al. (in press). Impacts of marine invasive alien species on ecosystem services and biodiversity: a pan-European critical review. Aquat. Invasions. doi: 10.3391/ai.2014.9.4.01

Katsanevakis, S., Zenetos, A., Belchior, C., and Cardoso, A. C. (2013). Invading European Seas: assessing pathways of introduction of marine aliens. Ocean Coast. Manag. 76, 64-74. doi: 10.1016/j.ocecoaman.2013.02.024

Klein, J., and Verlaque, M. (2008). The Caulerpa racemosa invasion: a critical review. Mar. Pollut. Bull. 56, 205-225. doi: 10.1016/j.marpolbul.2007.09.043

Kruskal, J. B. (1964). Multidimensional scaling by optimizing goodness of fit to a nonmetric hypothesis. Psychometrika 29, 1-27. doi: 10.1007/BF02289565

Lejeusne, C., Chevaldonne, P., Pergent-Martini, C., Boudouresque, C. F., and Perez, T. (2010). Climate change effects on a miniature ocean: the highly diverse, highly impacted Mediterranean Sea. Trends Ecol. Evol. 25, 250-260. doi: 10.1016/j.tree.2009.10.009

Macias, D., Garcia-Gorriz, E., and Stips, A. (2013). Understanding the causes of recent warming of Mediterranean waters. How much could be attributed to climate change? PLOS ONE 8:e81591. doi: 10.1371/journal.pone. 0081591

May, R. M. (1995). Conceptual aspects of the quantification of the extent of biological diversity. Philos. Trans. R Soc. Lond. B Biol. Sci. 345, 13-20. doi: 10.1098/rstb.1994.0082

Micheli, F., Halpern, B. S., Walbridge, S., Ciriaco, S., Ferretti, F., Fraschetti, S., et al. (2013). Cumulative human impacts on Mediterranean and Black Sea marine ecosystems: assessing current pressures and opportunities. PLoS ONE 8:e79889. doi: 10.1371/journal.pone.0079889

Molnar, J. L., Gamboa, R. L., Revenga, C., and Spalding, M. D. (2008). Assessing the global threat of invasive species to marine biodiversity. Front. Ecol. Environ. 6, 458-492. doi: 10.1890/070064

Mouillot, D., Albouy, C., Guilhaumon, F., Ben Rais Lasram, F., Coll, M., Devictor, V., et al. (2011). Protected and threatened components of fish biodiversity in the Mediterranean Sea. Curr. Biol. 21, 1044-1050. doi: 10.1016/j.cub.2011. 05.005

Nunes, A. L., Katsanevakis, S., Zenetos, A., and Cardoso, A. C., (2014). Gateways to alien invasions in the European Seas. Aquat. Invasions. 9, 133-144. doi: 10.3391/ ai.2014.9.2.02

Occhipinti Ambrogi, A. (2000). Biotic invasions in a Mediterranean Lagoon. Biol. Invasions 2, 165-176. doi: 10.1023/A:1010004926405

Olden, J. D. (2006). Biotic homogenization: a new research agenda for conservation biogeography. J. Biogeogr. 33, 2027-2039. doi: 10.1111/j.13652699.2006.01572.x

Por, F. D. (2009). Tethys returns to the Mediterranean: success and limits of tropical re-colonization. Biorisk 3:5e19. doi: 10.3897/biorisk.3.30

Sala, E., Kizilkaya, Z., Yildirim, D., and Ballesteros, E. (2011). Alien marine fishes deplete algal biomass in the eastern Mediterranean. PLOS ONE 6:e17356. doi: 10.1371/journal.pone.0017356

Schlaepfer, M. A., Sax, D. F., and Olden, J. D. (2011). The potential conservation value of non-native species. Conserv. Biol. 25, 428-437. doi: 10.1111/j.15231739.2010.01646.x

Shin, Y. J., Shannon, L. J., and Cury, P. M. (2004). Simulations of fishing effects on the southern Benguela fish community using an individual-based model: learning from a comparison with ECOSIM. Afr. J. Mar. Sci. 26, 95-114. doi: $10.2989 / 18142320409504052$

Simberloff, D., Martin, J. L., Genovesi, P., Maris, V., Wardle, D. A., Aronson, J., et al. (2013). Impacts of biological invasions: what's what and the way forward. Trends Ecol. Evol. 28, 58-66. doi: 10.1016/j.tree.2012.07.013

Spalding, M. D., Fox, H. E., Allen, G. R., Davidson, N., Ferdaña, Z. A., Finlayson, M., et al. (2007). Marine ecoregions of the world: a bioregionalization of coastal and shelf areas. Bioscience 57, 573-583. doi: 10.1641/ B570707

Trombetti, M., Katsanevakis, S., Deriu, I., and Cardoso, A. C. (2013). EASINLit: a geo-database of published alien species records. Manag. Biol. Invasions 4, 261-264. doi: 10.3391/mbi.2013.4.3.08

Trujillo, P., Piroddi, C., and Jacquet, J. (2012). Fish farms at sea: the ground truth from Google Earth. PLoS ONE 7:e30546. doi: 10.1371/journal.pone.0030546

Vilà, M., Basnou, C., Pysek, P., Josefsson, M., Genovesi, P., Gollasch, S., et al. (2010). How well do we understand the impacts of alien species on ecosystem services? A pan-European, crosstaxa assessment. Front. Ecol. Environ. 8:135-144. doi: $10.1890 / 080083$

Wallentinus, I., and Nyberg, C. D. (2007). Introduced marine organisms as habitat modifiers. Mar. Pollut. Bull. 55, 323-332. doi: 10.1016/j.marpolbul.2006.11.010 
Walther, G.-R., Roques, A., Hulme, P. E., Sykes, M. T., Pyšek, P., and Kühn, I. (2009). Alien species in a warmer world: risks and opportunities. Trends Ecol. Evol. 24, 686-693. doi: 10.1016/j.tree.2009.06.008

Whitehead, P., Bauchot, L., Hureau, J., Nielsen, J., and Tortonese, E. (1986). Fishes of the North-Eastern Atlantic and the Mediterranean. Paris: UNESCO.

Zenetos, A., Gofas, S., Morri, C., Rosso, A., Violanti, D., García Raso, J. E., et al. (2012). Alien species in the Mediterranean Sea by 2012.A contribution to the application of European Union's Marine Strategy Framework Directive (MSFD). Part 2. Introduction trends and pathways. Mediterr. Mar. Sci. 13, 328-352. doi: $10.12681 / \mathrm{mms} .327$

Zenetos, A., Gofas, S., Verlaque, M., Çinar, M. E., García Raso, E., Azzurro, E., et al. (2010). Alien species in the Mediterranean by 2010. A contribution to the application of European Union's Marine Strategy Framework Directive (MSFD). Part I. Spatial distribution. Mediterr. Mar. Sci. 11, 381-493. doi: 10. $12681 / \mathrm{mms} .87$

Conflict of Interest Statement: The Associate Editor Christos Dimitrios Arvanitidis declares that, despite being affiliated to the same institution as author Argyro
Zenetos, the review process was handled objectively and no conflict of interest exists. The authors declare that the research was conducted in the absence of any commercial or financial relationships that could be construed as a potential conflict of interest.

Received: 20 May 2014; accepted: 23 July 2014; published online: 30 September 2014. Citation: Katsanevakis S, Coll M, Piroddi C, Steenbeek J, Ben Rais Lasram F, Zenetos A and Cardoso AC (2014) Invading the Mediterranean Sea: biodiversity patterns shaped by human activities. Front. Mar. Sci. 1:32. doi: 10.3389/fmars.2014.00032

This article was submitted to Marine Ecosystem Ecology, a section of the journal Frontiers in Marine Science.

Copyright $\odot 2014$ Katsanevakis, Coll, Piroddi, Steenbeek, Ben Rais Lasram, Zenetos and Cardoso. This is an open-access article distributed under the terms of the Creative Commons Attribution License (CC BY). The use, distribution or reproduction in other forums is permitted, provided the original author(s) or licensor are credited and that the original publication in this journal is cited, in accordance with accepted academic practice. No use, distribution or reproduction is permitted which does not comply with these terms. 